\title{
SINTESIS HEPTAPEPTIDA LINEAR (H-TYR-ASP-PRO-ALA-PRO-PRO-PRO-OH) DENGAN MENGGUNAKAN DIC/OKSIMA SEBAGAI REAGEN PENGKOPLING
}

\author{
Rani Maharani dan Eka Fitri Yanti \\ Departemen Kimia Fakultas Matematika dan Ilmu Pengetahuan Alam Universitas \\ Padjadjaran \\ Email: r.maharani@unpad.ac.id
}

\begin{abstract}
A tetrapeptide, an analog of trypsin-modulating oostatic factor (TMOF), has been synthesised by using a method of solid-phase peptide synthesis on 2-chlorotrityl chloride resin. Fmoc strategy was applied on the synthesis. The formation of peptide bond was facilitated by DIC/oxime as coupling reagent. After all of amino acids were attached on the resin, tetrapeptidyl resin was added by a mixture of TFA:water:EDT(90:5:5) in dichloromethane to cleave the peptide.Crude peptide was purified by reverse-phase column chromatography and the purified peptide was analysed by TOF ES-MS spectroscopy.
\end{abstract}

Keywords: TMOF, heptapeptide, solid-phase peptide synthesis, DIC/oxyma, Crocidolomia pavonana.

\section{PENDAHULUAN}

Tanaman kubis merupakan salah satu komoditas sayuran yang memiliki nilai komersial dan prospek yang tinggi. Perkembangan produksi kubis selama periode 2000-2011 cenderung naik sebesar 2,05\% dan cenderung fluktuatif berdasarkan data dari Pusat Data dan Sistem Pertanian tahun 2013. Sebanyak 20,38\% produksi kubis di Indonesia berasal dari Provinsi Jawa Tengah dan 19,86 \% dari Jawa Barat. Namun pada tahun 2011, produksi kubis di Pulau Jawa justru mengalami penurunan sebesar 0,33\% jika dibandingkan dengan tahun 2000 (Sudarwohadi, 1975 dalam Uhan, 2007). Salah satu penyebab turunnya produksi kubis adalah hama pertanian yang menyerang dan menurunkan produksi kubis. Hama tersebut adalah hama ulat krop kubis (Crocidolomia pavonana).

Hama ulat krop kubis (Crocidolomia pavonana) dapat meningkatkan kerusakan dari hasil produksi dan kualitas produksi kubis. Serangan yang timbul kadang-kadang sangat berat sehingga tanaman kubis tidak membentuk krop sehingga terjadi kegagalan panen. Kehilangan hasil kubis oleh serangan hama dapat mencapai 10\%-90\% (Rueda and Shelton, 2008).

Para petani umumnya mengatasi gangguan ulat kubis menggunakan insektisida sintetik. Namun, penggunaan insektisida sintetik secara terus-menerus menyebabkan banyak kerugian. Dampak kerugian yang ditimbulkan pestisida, dapat dikelompokkan atas 3 bagian: 1. pestisida berpengaruh negatif terhadap kesehatan manusia, 2. pestisida berpengaruh buruk 
terhadap kualitas lingkungan, dan 3. pestisida meningkatkan perkembangan populasi jasad penganggu tanaman (Girsang, 2009).

Salah satu upaya untuk mengurangi dampak negatif tersebut adalah penggunaan insektisida alami yang ramah lingkungan karena potensi untuk mengalami degradasi secara alami sangatlah mungkin (Arnason et al., 1993). Salah satu insektisida alami tersebut adalah insektisida dari golongan peptida, trypsin-modulating oostatic factor (TMOF). TMOF telah terbukti memiliki aktivitas insektisida pada larva nyamuk Aedes aegypty (Borovsky et al., 1993) dan larva Tobacco budworm (Heliothis virescens; Lepidoptera) (Nauen et al., 2002) yang bekerja melalui penghambatan biosintesis tripsin.

TMOF merupakan suatu dekapeptida (Pro-Pro-Pro-Pro-Pro-Pro-Ala-Pro-Asp-Tyr$\mathrm{NH}_{2}$ ) yang diisolasi dari ovarium nyamuk Aedes aegypty betina (Borovsky, 2003) dan disintesis oleh tubuh nyamuk tanpa ikut proses metabolisme dalam tubuh nyamuk betina (Borovsky, 2003). Studi TMOF sudah banyak digunakan termasuk studi yang berhubungan dengan isolasinya dari nyamuk Aedes aegypty dan sintesis kimianya. Studi aktivitas biologi TMOF dan analog-analognya juga sudah banyak dibahas terhadap beberapa spesies nyamuk.

Dalam studi kali ini, akan dikemukakan sintesis analog dari TMOF yaitu H-Tyr-AspPro-Ala-Pro-Pro-Pro-OH dengan metode sintesis peptida fasa padat. Sintesis senyawa heptapeptida ini didasarkan pada metode sintesis senyawa TMOF yang telah dilaporkan oleh Maharani et al. (2015).

\section{METODE PENELITIAN}

\section{Bahan}

Bahan-bahan yang digunakan dalam penelitian ini adalah resin 2-klorotritil klorida, Fmoc-prolin-OH, Fmoc-alanin-OH, Fmoc-Tyr $(t-\mathrm{Bu})-\mathrm{OH}, \quad$ Fmoc-Asp $(t-\mathrm{Bu})-\mathrm{OH}, \quad N-N-$ diisopropiletilamina (DIPEA), etil 2-siano-2-(hidroksiimino)asetat (oksima), asam triflouroasetat (TFA), etanol triflouroasetat (TFE), piperidin, berbagai jenis pelarut teknis dan pro-analis seperti diklorometana, dimetilformamida (DMF), $N$ - $N$-diisopropilkarbodiimida (DIC), akuades, metanol, kloroform, asam asetat, kloranil, asetaldehid, silika GF254, ODS RF18, plat ODS dan plat silika GF254.

\section{Prosedur Kerja}

\section{Pengikatan Asam Amino Ujung -C Pertama}

Sebanyak 0,25 g resin 2-klorotritil klorida (1,0-1,6 mmol klorida/g resin) disuspensikan dalam pelarut diklorometana, kemudian dikocok selama 5 menit dan disaring. Larutan 0,5 mmol Fmoc-prolin-OH dan 1,25 mmol DIPEA dilarutkan dalam $2 \mathrm{~mL}$ diklorometana, lalu ditambahkan ke dalam resin dan dikocok selama 30 menit pada suhu ruang. Resin disaring, kemudian dicuci dengan DMF (2x2 menit). Sebanyak 2,5 mL campuran diklorometana/metanol/DIPEA (80:15:5) ditambahkan ke resin yang kemudian 
dikocok selama 10 menit. Resin disaring dan perlakuan diulangi sekali lagi. Resin dicuci dengan 3 x 2,5 mL DMF dan 3 x 2,5 mL diklorometana lalu disaring hingga kering.

\section{Pelepasan Gugus Pelindung Fmoc}

Reagen pelepas gugus pelindung Fmoc, piperidin 25\% dalam DMF $(v / v)$ ditambahkan hingga resin terendam dan campuran reaksi dikocok selama 30 menit. Reagen pelepas gugus pelindung kemudian dikeluarkan dengan cara filtrasi. Perlakuan ini dilakukan hingga 5-6 kali. Setelah itu resin dicuci dengan DMF 5 kali dan diklorometana 3 kali. Reaksi sempurna jika tidak terdapat noda pada plat KLT di bawah sinar UV dengan panjang gelombang 254 $\mathrm{nm}$.

Beberapa miligram resin disisihkan dan ditambahkan $3 \mathrm{ml}$ larutan piperidin $20 \%$ dalam DMF, dikocok selama 5-10 menit, dan diencerkan 10x untuk diukur absorbansinya pada panjang gelombang $290 \mathrm{~nm}$. Perhitungan loading resin (pemuatan resin terhadap asam amino) sebagai berikut:

$$
\text { loading }\left(\frac{m m o l}{g}\right)=\frac{A b s_{\text {sampel }} x \text { pengenceran }}{\text { massa sampel } x 1,75}
$$

\section{Penyusunan Fragmen Peptida}

Fmoc-prolin-OH (4 ekuivalen) dan oksima (4 ekuivalen) ditimbang dalam tabung reaksi kering. Pelarut DMF ditambahkan sesedikit mungkin sampai reagen larut. DIC (4 ekuivalen) ditambahkan dan diaduk secara menyeluruh hingga larutan berwarna kuning dan larutan tidak panas. Larutan dicampurkan dengan resin dalam tabung SPPS dan diaduk perlahan selama 30 menit. Efektivitas kopling dianalisis dengan uji kloranil. Hasil uji positif (reaksi kopling belum sempurna) ditunjukkan dengan larutan berwarna kuning dan butiran resin berwarna hitam, campuran dikocok kembali selama 30 menit. Jika resin masih menunjukkan hasil positif setelah 4 jam, resin dicuci dengan 5x DMF dan 3x diklorometana dan reaksi kopling diulangi dengan reagen segar selama satu malam. Hasil uji negatif (reaksi kopling sempurna) ditunjukkan dengan larutan yang tidak berwarna dengan butiran resin berwarna kekuning-kuningan, maka resin dicuci dengan 5x DMF dan 3x diklorometana. Lalu dilanjutkan ke tahap pelepasan gugus pelindung Fmoc.

Urutan asam amino berikutnya yakni, Fmoc-prolin-OH, Fmoc-Ala-OH, Fmoc-prolin$\mathrm{OH}$, Fmoc-Asp $(t-\mathrm{Bu})-\mathrm{OH}$, dan $\mathrm{Fmoc}-\mathrm{Tyr}(t-\mathrm{Bu})-\mathrm{OH}$, disusun dengan menggunakan prosedur kopling dan pelepasan gugus pelindung Fmoc yang sama sampai tersusun peptida dengan urutan residu asam amino yang sesuai.

\section{Pelepasan Peptida Dari Gugus Samping Dan Resin}

Gugus pelindung rantai samping dilepaskan dari peptida bersamaan dengan pelepasan peptida dari resin dengan penambahan campuran TFA:air:EDT (90:5:5) ke peptida 
bergugus pelindung yang dikocok selama 1 jam pada suhu ruang. Campuran kemudian dikisatkan in vacuo, lalu dicuci dengan diklorometana beberapa kali.

Terlepasnya peptida dari resin ditandai dengan berubahnya warna resin menjadi merah terang. Resin disaring dan dicuci dengan diklorometana. Filtrat ditempatkan dalam labu evap yang sebelumnya sudah ditimbang. Filtrat dipekatkan dengan rotary evaporator dengan penambahan diklorometana secara bertahap agar TFA cepat menguap. Kemudian beberapa miligram sampel diambil untuk uji KLT dengan eluen metanol dan air (1:1) dengan TFA $10 \%$ menggunakan plat ODS untuk melihat kemurnian dari krud. Krud ditimbang dan siap untuk dimurnikan.

\section{Uji Karakterisasi dengan TOF ES-MS.}

Peptida yang sudah dikeringkan, diambil sedikit dengan ujung spatula dan ditempatkan dalam tabung eppendorf. Peptida kemudian ditambahkan dengan 2\% TFA (20 $\mu \mathrm{L}$ TFA dalam $1 \mathrm{~mL}$ diklorometana) hingga resin berubah warna menjadi merah. Setelah itu, peptida disaring dan ditambahkan metanol hingga $1 \mathrm{~mL}$ dalam tabung eppendorf. Lalu diuji dengan spektroskopi TOF ES-MS untuk mengetahui apakah susunan rantai peptida sudah tepat atau belum.

\section{Pemurnian Krud Dengan Kromatografi Fase Terbalik}

Preparasi sampel krud dilakukan dengan metode impreg kering, dimana krud peptida yang berada dalam labu evap dilarutkan dalam metanol seminimal mungkin dan ditambahkan dengan silika ODS hingga krud terserap dengan baik. Tahap ini dilakukan terus menerus hingga krud menjadi serbuk halus.

Silika ODS dibuat menjadi bubur terlebih dahulu dengan menambahkan larutan metanol hingga terendam seluruhnya selama semalam. Kolom disiapkan dengan mengalirkan larutan metanol dan menguji aliran pelarutnya. Setelah itu, kolom yang berisi larutan metanol ditambahkan bubur ODS yang sudah didiamkan semalam. Lalu, kolom yang berisi bubur dielusi dengan larutan metanol 2-3x agar kolom ODS tidak kering. Setelah itu, kolom dielusi dengan air. Kolom yang sudah dielusi dengan air siap untuk dimasukkan residu peptida yang sudah diimpreg. Lalu kolom dielusi dengan eluen bergradien metanol (0-100\%) dalam air dengan kehadiran TFA $10 \%$. Eluat ditampung pada tiap botol vial berdasarkan eluen yang ditambahkan.

Tiap eluat yang sudah ditampung, dianalisis dengan KLT menggunakan plat ODS dengan eluen metanol:air (1:1) (v/v) dengan kehadiran TFA 10\%. Selain itu, fraksi hasil kolom juga dianalisis dengan KLT menggunakan plat silika dengan pelarut propanol:air $(70: 30)(v / v)$. Fraksi potensial atau fraksi yang memberikan noda yang tampak pada UV $\lambda$ 254nm dikarakterisasi dengan ESI-MS. Uji kemurnian dilakukan dengan KLT analitik yang menunjukkan noda murni. 


\section{Uji Kualitatif SPPS}

\section{Uji Kloranil}

Beberapa butir resin disampling dan ditempatkan pada tabung reaksi kecil. Ke dalam butir resin tersebut ditambahkan 2-5 tetes larutan $1^{*}$ dan larutan $2^{*}$. Campuran reaksi diaduk pada suhu kamar selama 5 menit. Hasil positif ditunjukkan dengan larutan berwarna kuning dan butiran resin berwarna hitam, sedangkan hasil negatif ditunjukkan dengan larutan yang tidak berwarna dengan butiran resin berwarna kekuning-kuningan.

*keterangan: larutan $1: 2 \%$ asetaldehid dalam DMF, larutan $2: 2 \%$ kloranil dalam DMF.

Kromatografi Lapis Tipis (KLT)

Sebanyak 1-2 mg atau 10-20 partikel resin kering ditempatkan dalam tabung reaksi kecil, lalu ditambahkan dengan 5 tetes TFE/diklorometana (2:8) dan dikocok selama 5 menit. Campuran reaksi ditotolkan pada plat KLT dan dielusi dengan menggunakan campuran kloroform/metanol/asam asetat (90:8:2). Selanjutnya, plat hasil KLT diamati pada panjang gelombang $254 \mathrm{~nm}$.

\section{HASIL DAN PEMBAHASAN}

Sintesis rantai linear senyawa H-Tyr-Asp-Pro-Ala-Pro-Pro-Pro-OH dilakukan dengan strategi Fmoc/tBu menggunakan resin 2-klorotritil klorida. Kombinasi DIC/oksima dipilih sebagai reagen kopling dalam setiap penyusunan rangkaian asam amino pada H-Tyr-AspPro-Ala-Pro-Pro-Pro-OH. Resin 2-klorotritil klorida dipilih karena gugusnya yang meruah sehingga dapat mengurangi terjadinya rasemisasi pada tahapan sintesis. Reagen kopling yang berupa kombinasi DIC/oksima dapat menghasilkan intermediet $O$-asilisourea yang bersifat labil sehingga mudah terbentuk ester aktif.

Sintesis peptida dilakukan dengan arah perpanjangan dari ujung-C ke ujung-N. Hal ini karena perpanjangan dengan arah sebaliknya, yaitu dari ujung-N ke ujung-C, amatlah rentan terhadap reaksi samping rasemisasi. Rasemisasi menyebabkan terjadinya perubahan konfigurasi absolut asam amino yang digabungkan (Chan \& White, 2000).

\section{Pengikatan Asam Amino Ujung-C Pertama}

Pengikatan asam amino ujung-C pada Fmoc-Pro-OH terhadap resin 2-klorotritil klorida dilakukan dengan menambahkan campuran reaksi antara Fmoc-Pro-OH dan DIPEA dalam diklorometana pada resin yang telah dikembangkan dalam diklorometana. Reaksi pengikatan asam amino pertama Fmoc-Pro-OH ke resin 2-klorotritil klorida tidak melibatkan aktivasi gugus karboksil sehingga dapat mencegah terjadinya reaksi rasemisasi. Reaksi yang terjadi 
hanyalah pengambilan hidrogen gugus karboksil pada Fmoc-Pro-OH (Gambar 1). Selanjutnya, nukleofil yang terbentuk menggantikan atom klorida $(*)$ pada atom karbon kuartener yang terdapat pada resin 2-klorotritil klorida. Dengan demikian, asam amino pertama Fmoc-Pro-OH dapat terikat pada resin. Penggunaan resin 2-klorotritil klorida dapat pula mencegah reaksi samping berupa pembentukan diketopiperazin karena meruahnya gugus aktif 2-klorotritil klorida tersebut. Resin 2-klorotritil klorida ini sangat sensitif terhadap air sehingga pada pelaksanaannya resin harus benar-benar dijaga dari air dan udara lembab (Chan \& White, 2000).

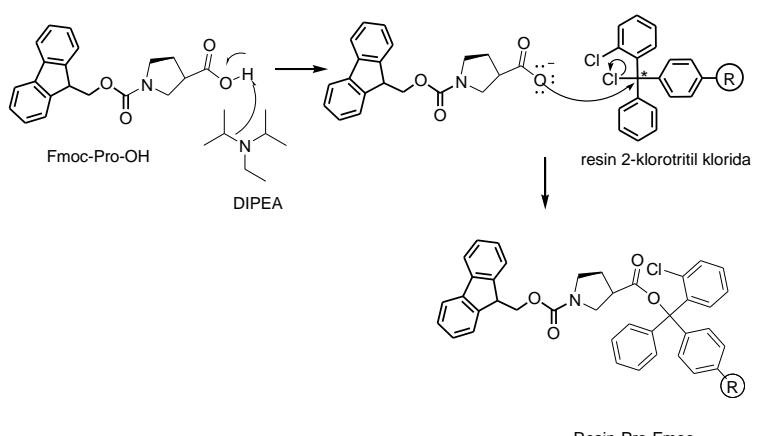

Gambar 1. Reaksi Pengikatan Asam Amino Ujung-C (Fmoc-Pro-OH) Ke Resin 2-Klorotritil Klorida.

Berdasarkan Gambar 1, tahap pengikatan asam amino dilewati melalui beberapa tahap reaksi. Reaksi pertama melalui reaksi asam basa antara Fmoc-Pro-OH dengan DIPEA terbentuk ion karboksil. Ion karboksil kemudian menyerang ion klorida (*) pada atom karbon kuartener resin 2-klorotritil klorida. Dengan demikian, asam amino pertama Fmoc-Pro-OH terikat pada resin. Atom klorida dengan tanda (*) merupakan gugus pergi yang sangat baik, karena dipengaruhi oleh tiga gugus benzena yang dapat menstabilkan intermediet. Atom klorida dapat disingkirkan oleh nukleofil lemah karboksil sekalipun (Chan \& White, 2000).

Reaksi pengikatan berlangsung selama 30 menit. Hal ini agar tidak terlalu banyak asam amino yang terikat pada resin yang akan mengganggu saat perpanjangan rantai peptida sehingga mempersulit asam amino bergugus pelindung menjangkau gugus $\alpha$-amino bebas.

Setelah asam amino prolin menempel pada resin, resin-Pro-Fmoc ditambahkan diklorometana/metanol/DIPEA dengan tujuan untuk menutup gugus aktif resin 2-klorotritil klorida yang tidak bereaksi dengan gugus metoksi. Hal ini dilakukan untuk mencegah asam amino selanjutnya bereaksi dengan gugus aktif resin yang masih tersisa.

Loading resin atau pemuatan resin dalam mengikat asam amino kemudian dihitung. Massa resin-peptida $(2,9 \mathrm{mg})$ ditambahkan dengan $3 \mathrm{~mL}$ larutan $20 \%$ piperidin dalam diklorometana dan dikocok selama 5-10 menit. Larutan diencerkan dengan pengenceran 10x dan diukur absorbansinya pada panjang gelombang $290 \mathrm{~nm}$. Absorbansi sebesar 0,262 diperoleh dan dimasukkan dalam persamaan sebagai berikut :

$$
\text { loading }\left(\frac{\mathrm{mmol}}{g}\right)=\frac{\text { Abs.sampel } x \text { pengenceran }}{\text { massa sampel } x 1,75}
$$




$$
\text { loading }\left(\frac{m m o l}{g}\right)=\frac{0,262 \times 10}{2,9 \times 1,75}
$$

Loading resin $=0,5163 \mathrm{mmol} / \mathrm{g}$

Hasil loading resin diperoleh sebesar $0,5163 \mathrm{mmol} / \mathrm{g}$ yang menandakan bahwa resin mampu mengikat asam amino dengan baik. Rata-rata loading resin yang baik berada pada 0,1-1,3 mmol/mg. Nilai loading resin terlalu besar menandakan bahwa populasi peptida yang menempel pada resin akan banyak. Hal ini kurang baik karena akan menyebabkan banyak peptida yang saling berdekatan. Akibatnya, proses penyusunan peptida (reaksi kopling) akan semakin sukar dan potensinya terjadi agregasi semakin besar. Keadaaan ini akan mengakibatkan reaksi kopling dan deproteksi akan semakin sulit.

\section{Pelepasan Gugus Pelindung Fmoc}

Gugus pelindung Fmoc dilepaskan dari $\alpha$-amino dengan penambahan larutan $25 \%$ piperidin dalam DMF.

Kesempurnaan reaksi pelepasan gugus Fmoc ditandai dengan tidak munculnya noda pada plat KLT (kromatografi lapis tipis) (di bawah lampu UV $254 \mathrm{~nm}$ ) setelah dideproteksi dengan penambahan piperidin yang menandakan bahwa gugus Fmoc sudah terlepas. Ini terjadi karena gugus pelindung Fmoc memiliki dua buah cincin benzen dengan elektron $\pi$ yang dapat terdelokalisasi diantara kedua cincin tersebut. Delokalisasi elektron $\pi$ ini menyebabkan gugus Fmoc dapat berpendar pada panjang gelombang UV $254 \mathrm{~nm}$. Lepasnya gugus Fmoc secara sempurna dari residu asam amino menyebabkan tidak munculnya pendaran noda pada plat KLT di bawah sinar UV 254 nm (Chan \& White, 2000).

\section{Penyusunan Peptida Linear}

Pada penelitian ini, penyusunan asam amino dilakukan dengan menggunakan reagen kopling kelompok karbodiimida dan oksima. Penggunaan aditif oksima dimaksudkan untuk menekan rasemisasi dan untuk efisiensi kopling yang lebih tinggi dari HOBt yang termasuk kelompok benzotriazol. Mekanisme reaksi dapat dilihat pada Gambar 2.

Campuran reaksi kopling dibuat dengan cara melarutkan campuran asam amino kedua, Fmoc-Pro-OH, dan oksima dalam pelarut DMF sesedikit mungkin sampai terbentuk larutan bening kekuningan yang homogen. Penambahan DMF dilakukan sedikit demi sedikit sambil dikocok dengan vortex, karena proses pelarutan asam amino bergugus pelindung dan oksima membutuhkan waktu yang cukup lama untuk dapat larut sempurna. Selanjutnya, DIC ditambahkan ke dalam campuran reaksi dan dikocok dengan menggunakan vortex. Saat ditambahkan DIC, larutan akan terasa panas namun setelah dikocok dengan vortex dalam waktu 10 menit akan terjadi perubahan warna, suhu dan kekentalan larutan. Perubahan ini menunjukkan bahwa ester aktif oksima asam amino Fmoc-Pro-OH telah terbentuk. 


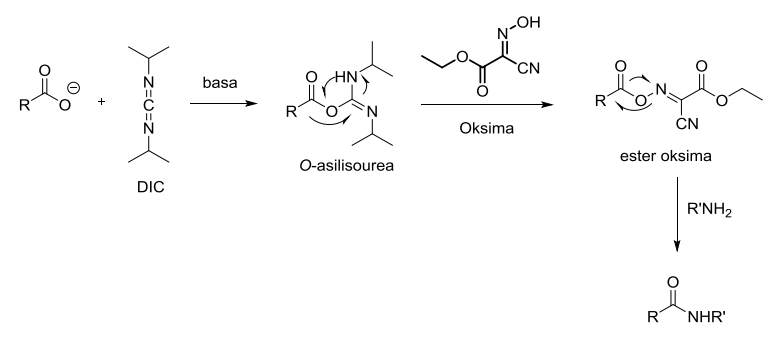

Gambar 2. Skema Mekanisme Reaksi Kopling Menggunakan DIC Dan Oksima.

Kesempurnaan reaksi kopling antara asam amino Fmoc-Pro-OH dan resin-Pro-NH dengan DIC/oksima terjadi setelah kopling selama satu malam. Reaksi kopling yang telah sempurna dianalisis dengan uji kloranil yang memberikan hasil negatif untuk keberadaan gugus amina sekunder dengan warna resin bening kekuningan. Ini menunjukkan bahwa asam amino prolin kedua yang terlindungi sudah menempel dengan asam amino pertama.

Tahap ini kemudian dilanjutkan dengan pelepasan gugus Fmoc yang memberikan resin-Pro-Pro-NH yang siap untuk reaksi kopling berikutnya.

Penambahan empat asam amino berikutnya dilakukan dengan tahapan protokol yang sama dan berulang dengan sebelumnya (kopling dan deproteksi Fmoc). Namun, sebagai catatan kopling berikutnya selalu diulang sebanyak 3 kali, karena sifat struktur yang lebih kompleks dan adanya rantai samping yang membuat asam amino yang menempel tidak sepenuhnya terikat pada resin. Skema kopling dan deproteksi asam amino secara lengkap dijelaskan pada Gambar 3.

Sejumlah kecil resin-Pro-Pro-Pro-Ala-Pro-Asp-Tyr-NH dilepas dengan beberapa tetes campuran TFA:air:EDT (90:5:5) dalam diklorometana. Lalu larutannya diuji dengan TOF ES-MS yang memberikan puncak pada $m / z$ 756,2538. Puncak ini mengindikasikan munculnya puncak ion molekul $[\mathrm{M}+\mathrm{H}]^{+}$untuk YDPAPPP sebesar 755,35. Hasil ini menunjukkan bahwa sintesis telah berhasil dan peptida siap untuk dilepas dari resin.

Heptapeptida yang masih terikat pada resin direaksikan dengan penambahan $10 \mathrm{~mL}$ campuran TFA:air:EDT (90:5:5) dalam diklorometana untuk melepas peptida dari resin. Terlepasnya peptida dari resin ditandai dengan berubahnya warna resin menjadi merah. Kemudian didapatkan berat krud sampel sebesar $150 \mathrm{mg}$.

Setelah peptida terlepas dari gugus rantai samping dan resin, filtrat diuapkan dengan rotatory evaporator hingga didapatkan krud kering senyawa heptapeptida. Kemudian sedikit krud kering diambil untuk dilakukan uji KLT menggunakan pelarut metanol : air (1:1) dengan kehadiran TFA $10 \%$.

Hasil uji KLT menunjukkan bahwa senyawa heptapeptida masih belum murni. Oleh karena itu, tahap pemurnian diperlukan dan kromatografi fase terbalik dengan ODS (oktadesil) yang bersifat non polar dipilih untuk tujuan pemurnian peptida target. 


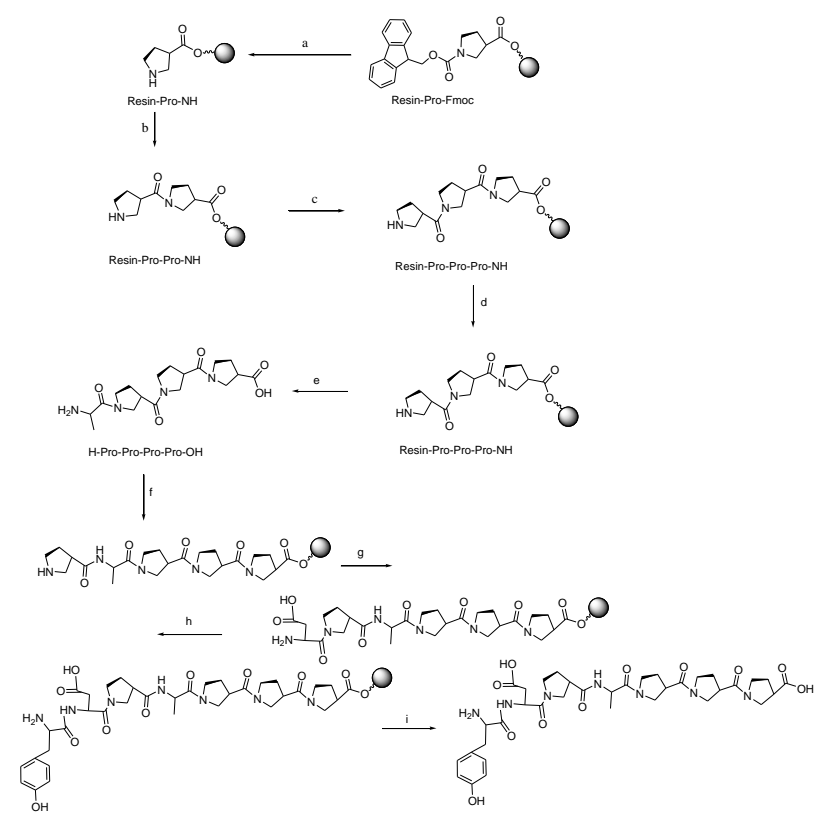

Gambar 3. Skema sintesis H-Tyr-Asp-Pro-Ala-Pro-Pro-Pro-OH. (a) 25\% piperidine in DMF, 30 minutes (b) (1) Fmoc-Pro, DIC/Oxyma, DMF (2) 25\% piperidine in DMF, 30 minutes (c) (1) Fmoc-Pro, DIC/Oxyma, DMF (2) 25\% piperidine in DMF, 30 minutes (d) (1) Fmoc-Pro, DIC/Oxyma, DMF (2) $25 \%$ piperidine in DMF, 30 minutes (e) (1) Fmoc-Ala, DIC/Oxyma, DMF (2) $25 \%$ piperidine in DMF, 30 minutes (f) Fmoc-Pro, DIC/Oxyma, DMF (2) 25\% piperidine in DMF, 30 minutes (g) Fmoc-Asp(tBu), DIC/Oxyma, DMF (2) 25\% piperidine in DMF, 30 minutes (h) Fmoc-Tyr(OtBu), DIC/Oxyma, DMF (2) 25\% piperidine in DMF, 30 minutes (i) TFA:air:EDT (90:5:5).

Pemilihan pemurnian menggunakan kromatografi fase terbalik didasarkan pada fakta bahwa peptida memiliki banyak gugus polar yang berpotensi membentuk ikatan hidrogen dengan gugus silanol dari silika gel, sehingga profil pemisahannya akan membentuk ekor yang sangat lebar. Hal ini menyebabkan, peptida tidak akan terpisahkan dari pengotornya dengan baik. Oleh karena itu gugus non-polar C18 dari ODS dipilih. Struktur ODS (silan terasilasi) yang masih memiliki gugus $\mathrm{SiO}$ akan tetap berpotensi melakukan interaksi sekunder (ikatan hidrogen). Untuk kasus ini, digunakan penambahan TFA pada saat dielusi dengan eluen bergradien metanol (0-100\%) dalam air. TFA sendiri akan memprotonasi gugus silan sehingga menekan potensi terbentuknya ikatan hidrogen pada peptida maka akan membuat hasil KLT tidak lebar dan tidak berekor (Chan and White, 2000).

Hasil pemurnian krud menghasilkan fraksi murni setelah dianalisis dengan KLT.

Setelah itu krud yang terdapat dalam fraksi tersebut dikisatkan dan diambil beberapa miligram untuk diuji MS dan diuji kemurnian menggunakan KLT. Persentase hasil krud setelah pemurnian untuk senyawa peptida 3,04\%.

Dari data TOF ES-MS, didapatkan puncak pada $\mathrm{m} / \mathrm{z}$ 756,2538. Puncak ini mengindikasikan munculnya puncak ion molekul $[\mathrm{M}+\mathrm{H}]^{+}$755,35 untuk H-Tyr-Asp-Pro-AlaPro-Pro-Pro-OH. (Gambar 4). Hal ini menunjukkan bahwa senyawa heptapeptida yang sudah dimurnikan dapat terdeteksi. 


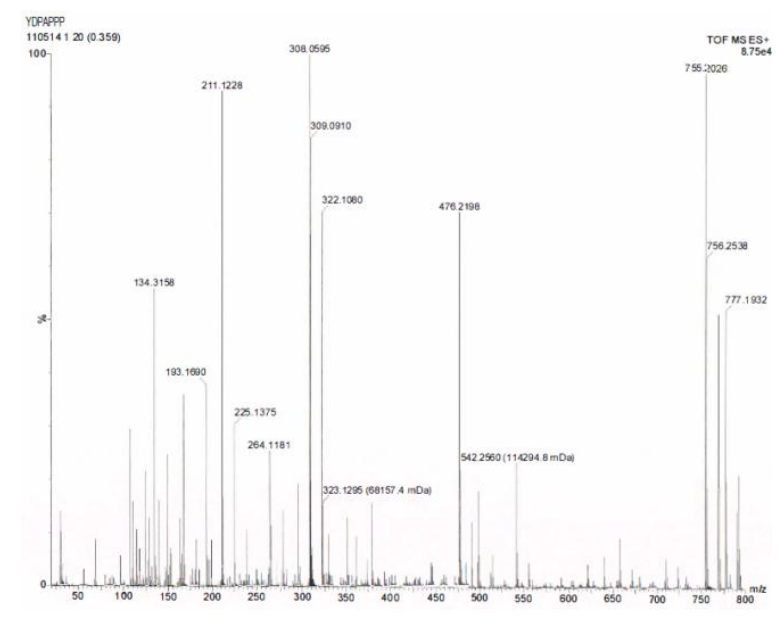

Gambar 4. Spektrum HR-TOF-MS ES ${ }^{+}$senyawa peptida analog H-Tyr-Asp-Pro-Ala-ProPro-Pro-OH. setelah dimurnikan

\section{PENUTUP}

Kesimpulan

Sintesis heptapeptida fase padat senyawa analog H-Tyr-Asp-Pro-Ala-Pro-Pro-Pro-OH. berhasil dilakukan dengan menggunakan kombinasi reagen kopling DIC/oksima. Hal ini ditandai dengan adanya puncak $\mathrm{m} / z$ pada spektrum MS pada puncak ion molekul $[\mathrm{M}+\mathrm{H}]^{+}$ 756,2538 setelah dianalisis dengan TOF ES-MS.

\section{Ucapan Terima Kasih}

Penulis ingin menyampaikan ucapan terima kasih kepada Indonesia Toray Science Foundation (ITSF) yang telah membantu penulis dalam menyediakan hibah penelitian.

\section{DAFTAR PUSTAKA}

Sudarwohadi, S. (1975). Pengaruh waktu tanam kubis dan dinamika populasi Plutella maculipennis Curt. dan Crocidolomia binotalis, Holtikultura, 3(4), p. 3-14.

Rueda, A. and Shelton, A.M. (2008). Diamonback Moth (DBM). Global Crop Pests. Cornell International Institute For Food, Agriculture, and Development.

Girsang, W. (2009). Dampak Negatif Penggunaan Pestisida. Fakultas Pertanian. Universitas Simalungun. Pematang Siantar.

Arnason, J.T., Mackinnon, S., Durst, A., Philogene, B.J.R., Hasbun, C., Sanchez, P., Poveda, L., San Roman, L., Isman, M.B., Satasook, C., Towers, G.H.N., Wiriyachitra, P., and Mclaughlin, J.L., (1993). Insecticides in tropical plantswith non-neurotoxic modes of action. Phytochemical Potentialof Tropical Plants. p. 107-151.

Borovsky, D., Carlson, D.A., Griffin, P.R., Shabanowitz, J., and Hunt, D.F., (1993). Mass spectrometry and characterization of Aedes aegypty Trypsin Modulating Oostatic Factor (TMOF) and its analogs. Insec. Biochem. Molec. Biol., 23, p.703-712. 
Nauen, R., Sorge, D., Sterner, A., and Borovsky, D. (2002). TMOF-like factor controls the biosynthesis of serine proteases in the larval gut of Heliothis virescens. Archives of Insect Biochemistry and Physiology. P.49-65.

Borovsky, D., (2003). Trypsin-modulating oostatic factor: a potential new larviside for mosquito control. Journal of Experimental Biology, 206, p.3869-3875.

Maharani, R., Yanti, E.F., Melati, D.I., and Sihotang, D. (2015). Synthesis of Trypsinmodulating Oostatic Factor (TMOF) and its Analogues by Solid-phase Peptide Synthesis Using DIC/Oxyma as Coupling Reagent. Procedia Chemistry, vol. 17, pp. 125-131

Chan, W. C. A. White., P.D. (2000). Fmoc solid phase peptide synthesis: A practical approach, Oxford University press, New York. 
